\title{
KURIKULUM PAI SERTA PROBLEMA WARGA AGRARIS SERTA IMPLEMENTASINYA DALAM PEMBELAJARAN
}

\author{
Sri Wahyuni \\ Jl. Sukajadi Pekanbaru \\ Pascasarjana UIN SUSKA Riau \\ 32190424921@students.uin-suska.ac.id \\ Amril M. \\ UIN Suska Riau \\ Jl. HR. Soebrantas Panam-Pekanbaru \\ amrilm@uin-suska.ac.id \\ Abu Bakar \\ UIN Suska Riau \\ Jl. HR. Soebrantas Panam-Pekanbaru \\ abu.bakar@uin-suska.ac.id
}

DOI: 10.46781/al-mutharahah.v18i2. 367

\begin{abstract}
This study aims to determine the pie curriculum and the problems of agrarian society and their implementation in learning. The method used in the preparation of this paper is a literature review method, in which the author collects various sources or references relevant to the material presented and then conducts a further study of the material. Informasi collection techniques used are books and journals. The results in the study of this paper are the PAI curriculum and the problems of agrarian society and its implementation in learning there is a relevance between the PAI curriculum and the problems of agrarian society which can be implemented in learning by using the value inculcation method which consists of inculcating moral, ethical and moral values.
\end{abstract}

Keywords: PAI curriculum, Agrarian Society, Learning

\begin{abstract}
Abstrak
Riset ini bertujuan buat mengenali kurikulum PAI serta problema warga agraris serta implementasinya dalam pendidikan. Tata cara yang digunakan dalam penataan makalah ini merupakan tata cara kajian pustaka, yang itu penulis mengumpulkan bermacam sumber ataupun reverensi yang relevan dengan modul yang di sajikan dan kemudian dilakukan pengkajian terhadap materi tersebut lebih lanjut. Tata cara pengumpulan data yang di gunakan ialah novel dan setiap hari. Hasil dalam kajian makalah ini merupakan kurikulum PAI serta problema masyarakat agraris serta implementasinya dalam pendidikan ada relevansi antara kurikulum pai dengan problema warga agraris yang bisa diimplementasikan pada pendidikan dengan memakai tata cara penanaman nilai yang terdiri dari penanaman nilai moral, etika ataupun akhlak.
\end{abstract}

Kata Kunci: Kurikulum PAI, Penduduk Agraris, Pendidikan. 


\section{A. Pendahuluan}

Apakah budaya agraris benar-benar ada saat ini, baik budaya agraris konvensional maupun budaya agraris masa kini? Visi linearitas sosial ini secara mutlak menjawab bahwa masa budaya agraris sudah berakhir. Kita kini telah sampai pada zaman budaya modern atau bahkan zaman data, bahkan zaman ketuhanan. Alvin Toffler, dua puluh tahun sebelumnya, dalam bukunya The Third Wave, menyuarakan kehati-hatian tentang penghancuran budaya agraris - apa yang disebutnya Arus Utama Kemajuan. Apalagi futuris berbeda: mayoritas mengumumkan matinya budaya agraris sebagai jaminan kehadiran budaya atau data modern.

Bagaimanapun, jelas, belum lama ini masyarakat petani benar-benar ada di Indonesia. Memang, di Jawa, budaya agraris telah menurun atau diremehkan karena ketiadaan lahan hortikultura dan eskalasi budaya atau data modern. Padahal, di tempat lain meneliti, Indonesia, budaya pedesaan masih hidup dan berkembang hingga saat ini. Menelusuri celah Jawa Timur, Bali dan Sulawesi, atau bahkan Papua dan NTT, Anda pasti akan melihat keberadaan budaya agraris yang asli. Ini menyiratkan bahwa kebangkitan budaya lain tidak benar-benar mendiskreditkan masyarakat yang berbeda: di sini kebangkitan budaya modern atau pendidikan tidak benar-benar melenyapkan budaya pekerja. Masyarakat tani, budaya modern, dan budaya data atau informasi benar-benar membentuk sebuah perkumpulan sosial (cloud) - yang kadang-kadang bekerja sama dan sesekali membingkai kepribadian mereka sendiri. Hal ini menunjukkan bahwa budaya agraris bukan hanya sesuatu dari masa lalu, tetapi juga sesuatu yang hadir di masa dan tempat sekarang.

Untuk alasan apa budaya agraris berkembang, atau bahkan berkembang, terlepas dari munculnya masyarakat modern dan data yang kelompok Toffler sebagai perkembangan gelombang kedua dan kedua? Selasa? Pertama, karena tanah (agribisnis) merupakan alasan mendasar bagi keberadaan budaya pedesaan yang benar-benar ada secara praktis. Meski berkurang di berbagai tempat di Jawa, namun meluas di berbagai tempat di luar Jawa. Pembebasan lahan hortikultura di luar Jawa sangat penting dan sejati serta dapat menjadi landasan atau akar yang kokoh bagi keberadaan budaya agraris; seperti halnya air atau lautan yang merupakan akar atau premis budaya bahari/marine/marine.

Kedua, individu atau jaringan yang mendasarkan realitasnya pada (transformasi) lahan menjadi agribisnis menghasilkan dalam jumlah yang cukup besar. Masyarakat umum atau daerah ini merupakan pemilik budaya agraris yang kemudian dikenal sebagai budaya agraris atau agraris. Mereka adalah elemen penentu dalam hidup dan matinya budaya hortikultura (bukan spesialis atau spesialis) karena masyarakat dan budaya secara konsisten berada dalam hubungan yang kooperatif dan proporsional.

Ketiga, kosmologi dan tatanan kehidupan (baik sosial-sosial, sosial-politik dan dunia lain) yang dianut oleh daerah penggarap tetap terjaga dan terpelihara meskipun pada kenyataannya sangat terkotak-kotak. Kami menyadari bahwa budaya agraris sangat terhormat dan dalam kerangka yang tepat, mantap dan stabil; Berbeda dengan budaya modern yang bergantung pada hiruk pikuk. Dengan demikian, signifikansi kosmologi dan tuntutan kehidupan menjadi vital dan sentral dalam budaya agraris. Kosmologi dan kerangka hidup ini mengikuti dan mengatur kehidupan mereka dan keberadaan budaya agraris. Selain itu, keempat, telah ditunjukkan bahwa baik budaya agraris maupun masyarakatnya terus bergerak menuju perubahan dengan tujuan akhir untuk bereaksi dan bereaksi terhadap berbagai perubahan yang terjadi dalam keadaan mereka saat ini; menggabungkan perubahan yang terjadi karena adanya kerangka kerja, budaya dan data, materi dan usaha sosial lainnya yang bernilai. 
Salah satu tatanan kehidupan yang dimiliki oleh setiap masyarakat umum atau daerah (baik agraris, modern atau berguna) adalah pelatihan dengan alasan bahwa setiap masyarakat umum tetap eksis (mengajar) dirinya sendiri dan masyarakat agar tetap eksis. Instruksi di sini dari perspektif yang luas: sebuah karya untuk mendidik, melatih, membimbing, dan mengarahkan siswa pada premis yang berkelanjutan. Dengan demikian, budaya agraris juga memiliki organisasi-organisasi edukatif sebagai kerja untuk mendidik diri sendiri dan jaringannya agar tetap eksis.

Sebagai suatu tatanan sosial-sosial, dalam budaya dan budaya agraris, pengajaran pada hakekatnya dan pada mulanya mempunyai kapasitas (i) membebaskan dan membebaskan daerah penggarap dari berbagai potensi hasil yang menjadikan daerah penggarapan itu bukan manusia; (ii) memperluas dan membina umat manusia sehingga budaya agraris berubah menjadi pribadi yang utuh; (iii) memungkinkan pengembangan jaringan untuk menciptakan dan mendukung keberadaan manusia dengan cara yang simpatik. Artinya, untuk budaya agraris, instruksi berubah menjadi perangkat dasar untuk pembebasan dan pemurnian. Selain itu, juga digunakan sebagai perangkat dasar untuk mewujudkan, mengikuti, memperoleh dan menumbuhkan keberadaan budaya dan budaya agraris. Sejalan dengan itu, sebagai tatanan sosial yang berbeda, dalam budaya dan masyarakat agraris, pelatihan dipandang sebagai alat untuk memperkuat dan meningkatkan kehadiran dengan kapasitas mengkoordinasikan dan mengubah harga diri daerah. budaya agraris.

\section{B. Metode Penelitian}

Metode yang digunakan dalam penelitian ini yaitu metode literature review dimana penulis mengumpulkan berbagai sumer atau referensi yang berhuungan dengan literatur yang disajikan kemudian melakukan penelitian lebih lanjut mengenai dokumen. Metode pengumpulan informasi yang digunakan merupakan dari buku dan jurnal yang ada yang berkaitan dengan judul yang ada.

\section{Pembahasan}

\section{Konsep Masyarakat Petani}

\section{a. Pengertian Masyarakat Agraris}

Budaya agraris adalah masyarakat umum yang mengandalkan bercocok tanam untuk panggilannya, baik di sawah maupun di pekarangan. Eksistensi kawasan lokal ini masih jauh dari modernisasi, khususnya yang masih berjalan dengan dasar kehidupan konvensional. Budaya saat ini adalah kolaborasi umum, yang tidak bisa dibedakan dari tradisi pedesaan.

Mereka tumbuh secara bertahap karena sedikit inovasi dan data, informasi dan kemampuan yang terbatas. Dia membuat mereka hidup dalam keterusterangan. Namun, ada juga membangun jaringan yang hidup dengan baik karena berbagai faktor seperti kekuatan, informasi, dan inovasi serta data yang lengkap.

Penduduk juga melakukan bisnis di luar area pertanian, misalnya, membuka toko makanan atau pergi ke kota selama musim sepi. Umumnya mereka menjadi buruh jalanan dan perancah atau buruh pembangunan. Dia menerima bahwa menjadi tenaga penjualan akan lebih mengembangkan ketenarannya lebih dari menjadi pekerja peternakan, pengangkut atau pengemudi cyclo.

Di sebagian besar jaringan kota, semua individu dari pamong kota dan pendidik kota diperlukan untuk mengklaim tanah, sawah dan ladang. Sebagian dari tanah tersebut disewakan dan hasilnya dipisahkan atau dijual 
ke peternak yang berbeda dan beberapa dari mereka bekerja sendiri. Dengan demikian, mereka lebih sering berada di lapangan daripada di belakang area kerja atau di ruang kelas. Meskipun demikian, mereka lebih suka menjadi pegawai pemerintah atau pendidik karena perwakilan membuat mereka lebih dihargai ${ }^{1}$.

ciri khas masyarakat agraris antara lain:

a) Adanya interaksi antar warganya.

b) Ada kebiasaan, standar, hukum, dan aturan khusus yang mengatur perilaku penduduk kota atau desa.

c) Kontinuitas waktu

d) Rasa identitas mengikat semua warga negara ${ }^{2}$.

Masyarakat agraris sangat erat hubungannya dengan masyarakat pedesaan. Di komunitas pedesaan, penduduk memiliki hubungan yang lebih dalam dan lebih dekat daripada di komunitas pedesaan lainnya di luar perbatasan mereka. Sistem kehidupan umumnya dikelompokkan atas dasar kekerabatan. Sebagian besar masyarakat pedesaan mencari nafkah dari pertanian. Warga negara identik, misalnya dalam hal mata pencaharian, agama, adat istiadat, dll. Poerwadarminta mendefinisikan petani sebagai seseorang yang mencari nafkah dari bercocok tanam di darat.

b. Karakteristik masyarat agraris

Adapun karakteristik dari masyarakat agraris adalah antara lain:

a) Perilaku yang homogen

b) Perilaku yang dilandasi oleh konsep kekeluargaan dan kebersamaan

c) Perilaku yang berorientasi pada tradisi dan status

d) Isolasi sosial, sehingga stati

e) Kesatuan dan keutuhan kultural

f) Banyak ritual dan nilai-nilai sakral

g) Kolektivisme ${ }^{3}$.

Jadi, masyarakat agraris adalah sekelompok orang yang saling berinteraksi dalam suatu bidang tertentu, mata pencaharian utamanya adalah pertanian atau mengubah hasil pertanian menjadi barang lain untuk melayani kebutuhan hidup. Sebagai bagian dari studi ini, masyarakat petani di desa Padang Kedeper sangat bergantung pada produk yang terbuat dari karet dan kelapa sawit.

\section{c. Lapisan/strata sosial dalam masyarakat agraris}

Berdasarkan kepemilikan tanah, penduduk pertanian dapat dibagi menjadi tiga kelas berikut:

a. Kelas tertinggi adalah petani yang memiliki tanah dan rumah.

b. Kelas menengah, yaitu di antara para petani yang tidak memiliki tanah pertanian, tetapi memiliki kebun dan rumah.

c. Komponen terbawah yaitu petani yang tidak memiliki lahan pertanian. 4

Selanjutnya, kita juga mencatat bahwa stratifikasi sosial masyarakat pertanian didasarkan pada kriteria ekonomi tertentu, yaitu:

\footnotetext{
${ }^{1}$ http://citrariski.blogspot.com/2021/12/masyarakat-agraris.html

${ }^{2}$ Koentjaraningrat, Pengantar Ilmu Antropologi, (Jakarta: PT Rineka Cipta, 2009), h. 155

${ }^{3}$ Koentjaraningrat, pengantar.. h. 130

${ }^{4}$ http://repository.usu.ac.id/bitstream/handle/123456789/45748/ChapterII.pdf;jsessionid=53, diaksehari minggu 7 oktober 2021
} 
a. Lapisan pertama adalah elit desa yang memiliki cadangan pangan dan pengembangan komersial.

b. Golongan kedua terdiri dari mereka yang hanya menimbun makanan.

c. Tingkatan ketiga terdiri dari orang-orang tanpa cadangan makanan dan cadangan perusahaan, bekerja untuk memenuhi kebutuhan perut untuk mempertahankan hidup.

Struktur sosial masyarakat petani memiliki beberapa tingkatan sebagai berikut: ${ }^{5}$

a. Pemilik tanah memiliki tanah tetapi menyewakannya kepada petani, yang hanya memiliki modal tetapi tidak memiliki tanah, sehingga petani yang memiliki tanah Pemilik tanah tetap menerima pendapatan dari sewa tanah meskipun ia bukan pemilik tanah dan tidak secara langsung mengelola tanah untuk budidaya.

b. Penyewa tanah Petani yang memiliki modal tetapi tidak memiliki tanah menyewakannya kepada pemilik tanah untuk bercocok tanam. Sebagian hasil panen diberikan kepada pemilik tanah sebagai tanda terima kasih telah menyewakan tanah, dan sebagian hasil panen dijual di pasar. Selama mengelola, ia dibantu oleh petani.

c. Buruh Pertanian Seorang petani tidak memiliki tanah dan modal untuk bercocok tanam dan akhirnya bekerja untuk seorang petani yang memiliki tanah dan modal. Pekerjaan buruh tani sendiri adalah mengelola lahan dengan tujuan untuk menanam dan memelihara tanaman, dengan harapan mendapatkan hasil dari tanaman tersebut.

Sebagai kesatuan sosial, masyarakat mengolah, tumbuh dan berkembang di areal tanah yang memanjang hingga persawahan. Namun, di

\section{Kurikulum PAI} desa-desa pesisir, mayoritas penduduknya adalah petani.

\section{a. Pengertian Kurikulum Pendidikan Islam}

Rencana ini dibuat dengan tujuan untuk memberikan bimbingan kepada penanggung jawab menyelenggarakan pendidikan, dalam membimbing perkembangan peserta didik, dalam mencapai tujuan yang diinginkan dirinya, keluarga, dan masyarakat yang diinginkan. Program dalam pengertian yang paling baru adalah serangkaian kegiatan yang memberikan pengalaman siswa (siswa) di bawah arahan dan tanggung jawab sekolah.

Program persekolahan Islam adalah metode pengajaran Islam sebagai latihan, informasi dan pertemuan yang secara sengaja dan efisien diberikan kepada siswa untuk mencapai tujuan pendidikan Islam. Secara keseluruhan, program pelatihan Islami adalah sekumpulan latihan, informasi, dan pertemuan yang sengaja dan efektif diberikan oleh pengajar kepada siswa sehubungan dengan tujuan pendidik.

Mengingat data di atas, program pengajaran Islam adalah bagian dari pelatihan yang ketat sebagai cara untuk mencapai tujuan. Artinya, untuk mencapai tujuan pendidikan Islam yang ketat, program pendidikan yang diperlukan adalah sesuai dengan tujuan pendidikan Islam dan sesuai dengan usia dan tingkat perkembangan, ilmu otak anak, dan kemampuan belajar.

5 Putri Novitasari, http://blog.unnes.ac.id/putrinovitasari/2015/11/28/struktur-sosialmasyarakat- petani-dan masyarakat-nelayan-di-kabupaten-brebes/, dakes hari Minggu tanggal 7 oktober 2021 


\section{b. Tujuan Kurikulum Pendidikan Agama Islam}

Program madrasah bertujuan untuk menanamkan renungan dalam pribadi dan hati yang lebih muda, beretika dan membina jiwa yang murni. Ini juga bertujuan untuk mendapatkan informasi terus-menerus, campuran informasi dan pekerjaan, keyakinan dan moral, serta penerapan hipotesis yang membumi dalam kehidupan sehari-hari ${ }^{6}$.

\section{c. Metode Kurikulum Pendidikan Agama Islam.}

Untuk Untuk merencanakan program pendidikan kependidikan Islam yang memikat dan bermanfaat, diperlukan teknik yang sesuai dengan substansi dan landasan sosial saat ini. Substansi dan landasan sosial terjadi di ruang kelas atau di mana saja dalam proses pendidikan dan pembelajaran. Untuk menggabungkan pembelajaran, diperlukan teknik yang layak. Syukri Zarkasyi, pengelola sekolah inklusi Gontor yang mutakhir, pernah berkata: "Al tariqatu ahammu min al maddah, walaakinna almudarrisa ahammu min al tariqah, wa ruh almudarris ahammu min almudarris nafsihi" (teknik, namun apa yang lebih diprioritaskan daripada pendidik adalah materinya) Signifikan, semangat pengajar lebih signifikan dari pada pendidik itu sendiri). Penegasan ini menegaskan bahwa strategi yang digunakan oleh instruktur akan sangat menentukan keberhasilan atau kekecewaan dari proses pendidikan dan pembelajaran intuitif.

Teknik adalah strategi yang digunakan oleh pengajar dan siswa dalam proses pendidikan dan pembelajaran. Dengan demikian, teknik merupakan sarana untuk menjalin kerjasama antara pengajar dan siswa dalam berkonsentrasi pada suatu materi tertentu. Untuk situasi ini pendidik berperan sebagai promotor, fasilitator, pembimbing, dan sebagainya. Sementara siswa dapat berperan aktif dalam latihan ini, Ahmad Tafsir mengatakan teknik madrasah yang digunakan oleh pengajar saat ini adalah efek samping dari strategi yang dibuat oleh orang Barat. Karena aset-aset ini saat ini tersedia secara efektif dan dapat digunakan untuk lebih mengembangkan teknik dan metodologi pembelajaran kami. Contoh teknik yang kami gunakan adalah wacana, konseptualisasi, tanya jawab, percakapan, sosialisasi, bermain, pengajian dan lain-lain. Untuk melaksanakan teknik, penting untuk melibatkan strategi instruktur yang tepat sesuai dengan visi dan misi mata pelajaran, tujuan mata pelajaran dan atribut mata pelajaran ${ }^{7}$.

Hal yang sama juga diungkapkan oleh Muhaimin et al., (2001), yang mengatakan bahwa teknik yang digunakan untuk melaksanakan program latihan keras Islam sangat sedikit tidak sama dengan strategi yang digunakan di persekolahan. Memang, pada dasarnya tidak ada kontras antara keduanya, tidak terlalu memperhatikan nama interaksi instruktif, pengaturan, atau bagian dari bidang, untuk menjadi intelektual, emosional, dan mental tertentu.

Oleh karena itu, ajaran Islam yang tegas harus ditujukan pada "perhatian" dari ketiga perspektif di atas. Ketiga bagian pembelajaran pendidikan Islam ini tidak dapat dipisahkan satu sama lain. Pedoman ini seperti yang ditunjukkan oleh A. Malik Fadjar, bahwa latihan keras Islam

${ }^{6}$ Heri Gunawan,Kurikulum dan Pembelajaran Pendidikan Agama Islam. Bandung: Alfabeta,

${ }^{7}$ Ahmad Tafsir, Ilmu Pendidikan Dalam Perspektif Islam, Bandung: Rosda karya, 1994. 
adalah interaksi edukatif yang dapat mengubah siswa menjadi orang Muslim sejati ${ }^{8}$.

d. Materi Kurikulum Pendidikan Agama Islam

Untuk merencanakan program pelatihan Islam yang menarik dan bermanfaat, diperlukan strategi yang sesuai dengan substansi dan setting sosial saat ini. Substansi dan setting sosial terjadi di ruang belajar atau di tempat lain dalam proses pengajaran dan pembelajaran. Untuk meringkas pembelajaran, diperlukan teknik yang berhasil. Syukri Zarkasyi, pengurus pesantren terdepan di Gontor, pernah berkata: "Al Taxqatu ahammu min al maddah, walaakinna almudarrisa ahammu min al taxqah, wa ruh almudarris ahammu min almudarris nafsihi" (teknik, namun lebih penting daripada mengajar) Individu adalah materi) Signifikan, semangat pendidik lebih diprioritaskan daripada instruktur itu sendiri). Pernyataan ini menegaskan bahwa teknik yang digunakan oleh pendidik akan sangat menentukan tercapai atau tidaknya proses pembelajaran yang cerdas.

Sesuai Mujtahid, ia menjelaskan bahwa tiga akidah di atas (keyakinan, Islam dan empati) diubah menjadi bagian-bagian informasi seperti Aqidah, Fiqh, Tasawuf, Kurma, dan sebagainya yang baru di tingkat surgawi, cenderung berpengaruh. Terlebih lagi anggapan bahwa orang miskin memiliki pilihan untuk bereaksi dan merespon dengan cepat terhadap perubahan dan kemajuan yang sedang terjadi saat ini. Pelajaran Islam harus mengacu pada pelajaran Al-Qur'an dan fantasi yang membawa perspektif yang lebih luas tentang nilai keberadaan manusia dan tidak pernah dibatasi oleh kenyataan ${ }^{9}$.

Pada awalnya, mata kuliah ini diharapkan dapat mengajarkan otak atau hati, khususnya materi yang berhubungan dengan ilmu ketuhanan, yang dapat diubah menjadi semua perkembangan dan langkah manusia. Ilustrasi ini bukan hanya sekedar kajian fiqih dan etika, tetapi juga ilmu yang membimbing manusia untuk mencapai kehidupan yang lebih tinggi dalam keseluruhan aspeknya. Kelima, item yang ditunjuk harus digariskan menurut arsip yang berbeda.

e. Evaluasi Kurikulum Pendidikan Agama Islam

Menentukan Memutuskan hasil atau interaksi dari suatu gerakan dan latihan membutuhkan apa yang dikenal sebagai penilaian. Penilaian adalah serangkaian realitas yang tepat untuk memutuskan apakah ada perubahan dalam siswa dan untuk menentukan tingkat kemajuan ini dalam siswa. menyatakan bahwa penilaian adalah suatu rangkaian penggambaran, pengumpulan dan pengenalan data yang berguna untuk menilai pilihan pilihan lain.

Sebagaimana ditunjukkan oleh Wayan Nurkancana dan Sumartana, penilaian adalah suatu kegiatan atau interaksi yang menentukan manfaat segala sesuatu dalam suatu gerakan edukatif, baik materi, pengajar, siswa maupun sudut pendukung lainnya. Penilaian digunakan untuk mengukur sejauh mana tujuan yang telah ditetapkan telah tercapai. Audit sangat berharga untuk membuat peningkatan. Sebagaimana ditunjukkan oleh Wayan Nurkancana dan Sumartana (1986), kapasitas evaluasi ini sebagai berikut:

8 A. Malik Fadjar, Visi Pembaruan Pendidikan Islam, Jakarta: Lembaga Pengembangan, Pendidikan dan Penyusunan Naskah Indonesia (LP3NI), 1998.

${ }^{9}$ Muhaimin, paradikma pendidikan islam, (bandung: Rosdakarta, 2004), h. 80 
Konsekuensi dari penilaian yang signifikan untuk pertemuan yang berbeda. Evaluasi penting untuk semua bagian dari sistem pembelajaran, terutama siswa, pendidik, wali, jaringan, dan sekolah atau halaman itu sendiri. Berdasarkan hasil evaluasi ini akan diputuskan tahapan dan strategi berikut yang akan disusun. Penilaian program pendidikan Islam yang ketat tidak hanya dinilai dari perangkat atau instrumen tes yang disusun, tetapi harus dilihat dari sudut pandang moral dan perilaku. Sejujurnya, latihan keras Islami lebih mudah dilihat dari ranah semangat dan mental daripada intelektual, meskipun kesadaran juga penting. Sorotan program pelatihan ketat Islam.

\section{Pembelajaran}

\section{a. Definisi Pembelajaran}

Belajar adalah suatu proses dimana siswa berinteraksi dengan sumber belajar dan pendidikan dalam suatu lingkungan belajar. Pembelajaran adalah bantuan pendidik untuk berlangsungnya proses memperoleh pengetahuan dan pengetahuan, menguasai keterampilan dan watak, serta membentuk sikap dan keyakinan pada diri peserta didik. Dengan kata lain, belajar adalah proses yang membantu siswa belajar dengan baik.

Belajar adalah kegiatan yang kompleks. Pada hakikatnya, belajar bukan hanya sekedar penyampaian pesan, tetapi juga merupakan kegiatan profesional yang menuntut guru untuk menggunakan keterampilan dasar mengajar secara terpadu dan menciptakan situasi yang efektif ${ }^{10}$.

Oleh karena itu, dalam pembelajaran, guru harus menciptakan suasana dan strategi pembelajaran yang kondusif yang membangkitkan minat belajar siswa. Kualitas pembelajaran sangat tergantung pada pembinaan kreativitas guru. Tujuan pembelajaran dapat diukur dari perubahan sikap dan kemampuan siswa selama proses pembelajaran. Desain pembelajaran yang baik, didukung dengan fasilitas penilaian, serta kreativitas guru, akan membantu siswa mencapai tujuan belajarnya dengan lebih mudah.

Trianto mengatakan "Belajar adalah aspek kompleks dari aktivitas manusia yang tidak dapat dijelaskan sepenuhnya". Belajar dapat dipahami secara sederhana sebagai produk dari interaksi berkelanjutan antara perkembangan dan pengalaman hidup. Pembelajaran kompleks adalah upaya sadar oleh guru untuk mengajar siswanya (mengarahkan interaksi siswa dengan sumber belajar lain) untuk mencapai tujuan yang diinginkan.

Hardini dan Puspitasari "Belajar adalah kegiatan yang disengaja untuk mengubah berbagai kondisi demi tercapainya suatu tujuan, yaitu tercapainya tujuan kurikulum".

Belajar adalah suatu proses dimana siswa berinteraksi dengan sumber belajar dan pendidikan dalam suatu lingkungan belajar. Pembelajaran adalah bantuan pendidik untuk berlangsungnya proses memperoleh pengetahuan dan pengetahuan, menguasai keterampilan dan watak, serta membentuk sikap dan keyakinan pada diri peserta didik. Dengan kata lain, belajar adalah proses yang membantu siswa belajar dengan baik.

10 Nana Sudjana, Dasar-Dasar Proses Belajar Mengaja, (Bandung. Sinar Baru Algensindo), 
Belajar adalah kegiatan yang kompleks. Pada hakikatnya, belajar bukan hanya sekedar penyampaian pesan, tetapi juga merupakan kegiatan profesional yang menuntut guru untuk menggunakan keterampilan dasar mengajar secara terpadu dan menciptakan situasi yang efektif ${ }^{11}$.

Oleh karena itu, dalam pembelajaran, guru harus menciptakan suasana dan strategi pembelajaran yang kondusif yang membangkitkan minat belajar siswa. Kualitas pembelajaran sangat tergantung pada pembinaan kreativitas guru. Tujuan pembelajaran dapat diukur dari perubahan sikap dan kemampuan siswa selama proses pembelajaran. Desain pembelajaran yang baik, didukung dengan fasilitas penilaian, serta kreativitas guru, akan membantu siswa mencapai tujuan belajarnya dengan lebih mudah.

Trianto mengatakan "Belajar adalah aspek kompleks dari aktivitas manusia yang tidak dapat dijelaskan sepenuhnya". Belajar dapat dipahami secara sederhana sebagai produk dari interaksi berkelanjutan antara perkembangan dan pengalaman hidup. Pembelajaran kompleks adalah upaya sadar oleh guru untuk mengajar siswanya (mengarahkan interaksi siswa dengan sumber belajar lain) untuk mencapai tujuan yang diinginkan.

Hardini dan Puspitasari "Belajar adalah kegiatan yang disengaja untuk mengubah berbagai kondisi demi tercapainya suatu tujuan, yaitu tercapainya tujuan kurikulum".Manusia adalah makhluk sosial dan sosial bahwa "Belajar sangat penting bagi keberadaan seseorang. Seorang anak (manusia) menghabiskan sebagian besar hari untuk menyadari sehingga ia berubah menjadi manusia dewasa. Orang secara konsisten dan konsisten belajar pada titik apa pun dan dimanapun mereka berada.Pembelajaran yang ideal dapat tercapai bila siswa dinamis di bawah arahan seorang instruktur yang berfungsi.Salah satu cara memberlakukan siswa dalam pembelajaran adalah dengan menerapkan metode pembelajaran dan pembelajaran.Selanjutnya, mendidik dengan pendekatan berkumpul akan lebih efektif dalam hal prosedur pengajaran dan pembelajaran diterapkan.

a. Sebagai alasan untuk menguraikan hal yang tersirat oleh belajar, definisi yang menyertainya akan dikemukakan terlebih dahulu: Hilgard dan Nook, berpendapat: Belajar dihubungkan dengan perubahan dalam perilaku individu terhadap keadaan tertentu yang disebabkan oleh pertemuan berulang dalam keadaan itu, di mana penyesuaian perilaku tidak dapat diklarifikasi atau didasarkan pada kecenderungan reaksi alami individu, perkembangan, atau keadaan sementara (misalnya, kelemahan obat, dan sebagainya)

b. Gagne, menyatakan bahwa: Belajar terjadi ketika keadaan dorongan bersama dengan substansi ingatan mempengaruhi siswa sehingga aktivitasnya (eksekusi) berubah dari waktu sebelum dia menghadapi keadaan ke waktu kemudian dia menghadapi keadaan sebelumnya.

c. Morgan, Purwanto, merekomendasikan: "Belajar adalah perubahan tingkah laku yang berlangsung lama yang terjadi karena latihan atau pengalaman".

d. Sardiman, Belajar adalah kemajuan tugas fisik, mental, dan proaktif menuju peningkatan watak manusia seutuhnya, yang mengandung

11 Nana Sudjana, Dasar-Dasar Proses Belajar Mengaja, (Bandung. Sinar Baru Algensindo), 
unsur keinovatifan, cita rasa dan harapan, bidang intelektual, emosional, dan psikomotorik.

\section{Kurikulun Pai Dengan Masyarakat Agraris}

$\mathrm{K}$ Dalam buku-buku instruktif humanisme, tidak ada lagi kekhasan postulat yang menyatakan bahwa: Watak dan pola pikir seorang individu (menghitung suatu perkumpulan, suatu negara), adalah hasil dari suatu perkembangan perjumpaan sosial dan sosial. Individu Jawa dengan kualitas diri Jawanya bukan karena kecenderungannya (organik fisiologis-mental bawaan), sehingga memiliki pola pikir Jawa, tetapi karena perjumpaan sosial dan sosial dalam keluarga dan masyarakat Jawa itu sendiri. Persamaannya berlaku untuk budaya agraris secara keseluruhan. Dalam pergaulan ini, oleh para pengamat sosial, budaya agraris diputuskan untuk mengalami akibat buruk dari sikap konvensional; Pola pikir ini juga dianggap sebagai penghalang yang sangat mengesankan untuk memiliki pilihan untuk membawa budaya agraris ini menuju budaya tingkat tinggi dan terkini, apakah itu valid dan mengapa?

Dalam era pembangunan selama ini, bermacam-macam program dan innovasi pembangunan yang dirancang dan diintrodusir oleh pemerintah. Gagasan Keluarga Berencana digalakkan. Gerakan kewiraswastaan juga digalakkan. Hidup sedernaha dan ekonomis juga digalakkan. Modernisasi pertanian juga digalakkan. Di samping itu juga banyak program pembangunan lainnya yang dirancang dan diintrodusir oleh pemerintah.

Sehubungan dengan seribu satu macam program pembangunan yang dimasyarakatkan oleh pemerintah itu, nampaknya begitu kuat dihambat dan dirintangi oleh mentalitas dari Masyarakat agararis. Bagaimana corak mentalitas dimaksud?

Untuk menyelidikinya, pola pikir agraris dibangun dalam monisme; itu adalah gagasan tentang jiwa yang dijiwai dan ditanamkan dengan begitu tegas di pusat sejarah internal masyarakat umum ini. Alam semesta pemikiran monis memiliki pusatnya dalam gagasan kesatuan: satu antara, satu antara dunia material dan dunia batin, satu antara realitas saat ini dan dunia yang tidak mencolok, dan satu di antara Tuhan dan binatang-binatang-Nya. Pada dasarnya pribadi tunggal, seperti halnya masyarakat umum atau negara, tentu bukanlah diri yang mandiri, namun merupakan "solidaritas satu kesatuan" di seluruh alam semesta. Masalah infeksi, pertumbuhan, kegagalan keamanan, dll, bukanlah masalah diri sendiri, melainkan keseluruhan alam semesta; apapun yang terjadi di bawah langit ini, semuanya tidak dapat dibedakan dari rahasia dan keseluruhan alam semesta.

Di seluruh alam semesta, orang tunggal dan diri daerah setempat berkewajiban untuk bertindak dengan sopan, tidak melompat dan membuat takjub; Keamanan masyarakat dan area lokal yang lebih luas terletak pada keramahan. Jika tidak, berbagai macam malapetaka, malapetaka, malapetaka akan datang, sebuah indikasi dari keseluruhan alam semesta yang masih "gerahgerah" terhadap kegiatan yang tidak sesuai. Jika ada musibah, kesulitan, wabah, atau masalah dan keadaan darurat apa pun, itu disebabkan oleh diri sendiri, tetapi kembali ke kemarahan pelanggaran kita.

Sisa dari otak monisme adalah melihat keseluruhan alam semesta sebagai wadah "kekuatan" dan suci. Kesuciannya tersebar dan dialamatkan pada bagianbagian tertentu dari alam semesta, misalnya pohon beringin, pohon palem, kuburan, harta karun, pemimpin klan, menteri/dukun konvensional, perintis yang mendapatkan wangsit, dll. Bagian-bagian alam semesta yang dianggap dikuduskan dan disucikan adalah tempat di mana individu "menyerah dan 
mengeluh tentang nasib mereka", termasuk tempat untuk meminta keamanan dan untuk dihindari berbagai jenis risiko atau bencana: pintu masuk hadiah dan permintaan harmoni terletak di belahan alam semesta yang dianggap suci dan suci. Akibatnya, individu normal harus hebat dalam menghormati (menghitung cinta) alamat suci ini.

Satu lagi sifat bawaan dari pertimbangan yang diminta oleh monisme adalah menguatnya minat untuk selalu mengikuti gaya hidup yang telah menjadi standar selama berabad-abad. Melakukan goncangan, melakukan lompatan yang unik dalam hubungannya dengan hal biasa, sama saja dengan melakukan "tidak ada kebiasaan", menyambut "kegagalan", dan itu tentu bukan perilaku yang patut dicontoh. Dalam pergaulan ini, sangat diminta untuk memikirkan kembali, khususnya merenungkan gaya hidup para pendahulu, meniru para pendahulu, terus-menerus meminta dan menunggu hadiah yang lebih tua. Karenanya ada hal yang disebut keselarasan sosial. Masih dalam hubungan ini, watak hidup sebagai komunalisme juga diperlukan: di atas segalanya hanyalah kepentingan dan persekutuan normal, termasuk ketahanan, kompromi, dan kekurangan otonomi individu. Merenungkan diri sendiri, terutama yang tidak sejalan dengan "suara kelompok", akan ditandai sebagai individu yang tidak tahu adat. Akibatnya, menjadi "makhluk moneter" yang berpegang teguh pada gagasan "sistem aturan mayoritas ala Barat" dengan mentalitas bercita-cita tinggi, akan dianggap tidak sesuai dengan pesan nenek moyang yang mempertahankan komunalisme dan permintaan tenang dari persahabatan.

Pengaruh pandangan monistik ini terhadap kemajuan kebudayaan Indonesia, tentu saja, sangat besar. Penonton sosial seperti Koentjaraningrat, Mukhtar Lubis, Mulden Boeke, geetz, masing-masing menyadari kesulitan dan kesulitan melewati dampak hambatan tersebut untuk memiliki pilihan untuk membawa negara ini menuju masyarakat yang diciptakan canggih. Hal ini dapat dibenarkan, karena setiap modernisasi dan upaya perbaikan secara konsisten menuntut perubahan mendasar sesuai dengan gaya hidup dan pekerjaan masyarakat umum. Dalam siklus ini, destructuring dan structuration tidak bisa dihindarkan, sebuah interaksi yang jelas-jelas perlu mengelola social request; dalam budaya agraris, tuntutan itu begitu kokoh dituntaskan dan dipadatkan dengan begitu kokoh, dan itulah penghalang terbaik bagi modernisasi dan usahausaha kemajuan dunia ${ }^{12}$.

Dari penegasan di atas, permintaan yang kaku dan konvensional, dengan asumsi diikuti, sebenarnya adalah produk atau hasil organik dari "program pendidikan" sosial yang telah berjalan dengan perjalanan sejarah. Lalu, bagaimana menyesuaikannya dengan rencana pendidikan PAI ${ }^{13}$.

Dari paparan di atas bahwasanya kurikulum pendidikan agama islam tidak hanya berpatokan pada keilmuan keagamaaan saja tetapi juga berfokus pada materi umun yang dimana pada kelompok kedu di jelaskan beberapa materinya salah satunya yaitu ilmu kealaman dan sain terapan.

\section{Implemntasi Kurikulum Pai Dan Problema Masyarakat Agraris Dalam Dalam Pembelajaran}

Arti penting dari teknik program pendidikan pie adalah untuk mencapai tujuan, sedangkan arti penting dari tujuan adalah untuk mendapatkan hasil yang ideal. Titik fokus pertimbangan dari para ahli perencanaan pendidikan tidak

${ }^{12}$ Sanapiah Faisal, sosiologi Pendidikan, surabaya:Usana Offset Printing. h. 134-138

${ }^{13}$ Haidar Putra Daulay, Pendidikan Islam dalan Pespektif Filsafat, (Jakarta: Khairisma Putra Utara, 2014), h. 94-95 
diragukan lagi penting untuk menangani sistem program pendidikan, karena keberhasilan atau kegagalan pelaksanaan program pendidikan sebagian besar dikendalikan oleh metodologi program pendidikan itu sendiri. Dengan demikian, metodologi perencanaan pendidikan, baik skala penuh maupun miniatur, memiliki kapasitas ganda, yaitu: Menyebarkan pesan program pendidikan PAI yang mencerahkan, memikat, dan informatif secara metodis untuk tujuan mendapatkan hasil yang ideal.

Bahwa pentingnya melaksanakan program pendidikan tidak dapat dipisahkan dari cara hidup budaya agraris itu sendiri, di mana budaya agraris justru mempertahankan kualitas sosialnya. Setelah memahami ciri-ciri daerah alinea, dan mengetahui dampak ideal darinya, maka kemudian dipilih teknik yang digunakan untuk pembelajaran, karena berkaitan dengan media yang harus digunakan.

Dari pembehasan kita sebelumnya dapat disimpulkan bahwa hubungan antara kurikulum pai dan problrma masyarakat agraris adalah terletak pada nilainilanya baik itu nilai akhlak, morah, maupunetika jadi pengimplementasiannya dalam pembelajaran ialah berfokus pada penanaman nilai bukan pada merubah ritual atau adat istiadat masyarakat agraris itu sendiri Sehingga penanaman nilai itu sendiri dapat terelisasikan. Setelah penanaman nilai itu terlelisasiama maka otomatos seiring berjalannya waktu maka prilaku dari masyarkata agraris itu sesuai dengan tujuan dari kurikulum pai dan akan mencapai pada hasil yang di ingikan.

Pada kata akhlak, selain mendasari maknanya pada nila atau norma, ternyata juga ditemui muatan nilai dan norma untuk kata moral dan etika dan seterusnya. Penekanan pada nilai dan norma untuk akhlak ditemukan pada pendapat K. Bertens misalnya," Ia mengungkap bahwa etika adalah kualitas dan standar yang menjadi pembantu bagi individu atau perkumpulan dalam mengendalikan perilakunya. Arti penting kualitas mendalam ini diambil oleh K. Bertens setelah meneliti kata kualitas etis yang terkandung dalam referensi Kata Besar Bahasa Indonesia dan menghubungkannya dengan realitas saat ini.

Hal yang sama tentang penempatan nilai dan norma pada moral, secara spesifik dijelaskan oleh Taylor bahwa setidaknya ada dua hal yang tidak dapat dipisahkan dari muatan makna moral, yakni 1. normative standards of evaluations dan 2. normative rules of conduct. Dimaksud dengan yang pertama adalah tentang adanya kriteria nilai yang digunakan oleh individu atau sekelompok masyarakat untuk menentukan apakah sesuatu atau perilaku seseorang itu tergolong baik atau tidak baik, diharapkan atau tidak diharapkan dan seterusnya. Sedangkan dimaksud dengan yang kedua adalah berupa prinsipprinsip yang memerintahkan seseorang atau sekelompok masyarakat berperilaku sesuai dengan apa yang disebut benar atau salah, apa kewajiban dan tanggung jawab yang mesti dilakukan oleh seseorang atau sekelompok masyarakat dalam lingkungan komunitas tertentu." Untuk muatan makna yang kedua ini diperkuat pula oleh Lorens Bagus misalnya," mengungkapkan, bahwa akhlak itu menyangkut kegiatan-kegiatan manusia yang dipandang sebagai baik/buruk, benar/salah, tepat/tidak tepat, atau menyang Cara seseorang bertingkah laku dalam hubungan dengar perang ain Sampai pada titik ini dapat dikatakan bahwa moral dan akhlak serta nama lain yang seumpamanya memiliki kedekatan karena memiliki dua sifat seperti disebutkan di atas, yakni nilai sebagai barometer standar perilaku dan desakan untuk berperilaku sesuai dengan prinsip-prinsip untuk menentukan suatu 
perilaku itu benar atau salah, kewajiban dan tanggung jawab yang mesti dilakukan seseorang atau kelompok dalam lingkungan sosial tertentu.

Untuk etika yang disebut juga dengan filsafat moral atau ilmy akhlak dalam Islam memiliki makna yang berbeda dengan akhlak, moral dan sebutan lainnya. Dalam kajian etika atau filsafat moraj dan/atau ilmu akhlak diskusinya lebih pada ranah analisis alasan. alasan yang diajukan tentang kenapa sebuah perilaku seseorang atay sekelompok masyarakat dinilai baik, benar atau tidak baik atau salah dan seterusnya. Franz Magnis-Suseno, misalnya mengemukakan bahwa etika merupakan filsafat atau pemikiran kritis dan mendasar tentang ajaran-ajaran, norma-norma, nilai- nilai serta kebiasaankebiasaan dan pandangan akhlak secara kritis. Hashi A.A misalnya, menyatakan pula bahwa etika itu lebih melacak tentang kenapa sebuah perilaku itu dinilai baik dan benar sedangkan perilaku yang lain dinilai tidak baik atau salah. Kemudian etika akan menelaahnya secara mendalam dan mendiskusikan apa prinsip-prinsip yang mendasari terhadap keputusan akhlak dan moral. ${ }^{14}$

Dari penegrtian di atas tentang nilai akhlak, moral dan etika adapun penerapannya dalam msyarakat agraris kemudian penerapannya terhapa penerapan nilai dalam kehidupan sehari-hari diantaranya yaitu saling tolong menolong dan bergotoroyong dalam bermasyarakat dan pengimplementasian dalam pembelajaran adalah sebagaimana dalam pembelajara pai juga banyak kita temui materi tentang saling tolong menolong baik itu terhadap keluarga sesama teman maupun orang masyarakat.

\section{Simpulan}

Masyarakat tani adalah masyarakat yang mata pencahariannya bergantung pada pertanian, baik di sawah maupun di perkebunan. Kehidupan masyarakat ini masih jauh dari modernisasi yaitu hidup sederhana dan tradisional. Budaya yang ada adalah gotong royong, diidentikkan dengan adat pedesaan.

Kurikulum adalah seperangkat rencana yang termasuk dalam program studi. Kurikulum juga dapat dipahami sebagai seperangkat upaya yang dilakukan oleh suatu lembaga pendidikan untuk mencapai tujuan yang telah disepakati. Kurikulum adalah sejenis desain instruksional yang mencakup semua pengalaman belajar yang diberikan sekolah kepada siswa.

pembelajaran adalah proses di mana siswa berinteraksi dengan pembelajaran dan sumber daya pendidikan dalam lingkungan belajar. Belajar adalah bantuan pendidik dalam proses terus menerus memperoleh pengetahuan dan pengetahuan, menguasai keterampilan dan karakter, serta membentuk sikap dan keyakinan di kalangan siswa.

Hasil penelitian artikel ini adalah permasalahan proyek kue dan masyarakat agraris serta implementasinya dalam pembelajaran. . di mana nilai-nilai etika, moral dan etika berlabuh. 


\section{DAFTAR PUSTAKA}

A. Malik Fadjar, Visi Pembaruan Pendidikan Islam, Jakarta: Lembaga Pengembangan, Pendidikan dan Penyusunan Naskah Indonesia (LP3NI), 1998.

Ahmad Tafsir, Ilmu Pendidikan Dalam Perspektif Islam, Bandung: Rosda Karya,1994.

Amril, Pendidikan Nilai Akhlak, Depok: PT Rajagrafindo Persia, 2021

Haidar Putra Daulay, Pendidikan Islam dalan Pespektif Filsafat, Jakarta: Khairisma Putra Utara, 2014

Heri Gunawan,Kurikulum dan Pembelajaran Pendidikan Agama Islam. Bandung: Alfabeta, 2013)

http://citrariski.blogspot.com/2010/12/masyarakat-agraris.html http://repository.usu.ac.id/bitstream/handle/123456789/45748/ChapterII.pdf;jsessio nid $=53$, diakses hari minggu 7 Oktober 2021

Koentjaraningrat, Pengantar Ilmu Antropologi, Jakarta: PT Rineka Cipta, 2009

Muhaimin, Paradikma Pendidikan Islam, Bandung: Rosdakarta, 2004

Nana Sudjana, Dasar-Dasar Proses Belajar Mengajar, Bandung. Sinar Baru Algensindo),

Putri Novitasari, http://blog.unnes.ac.id/putrinovitasari/2015/11/28/struktur-sosialmasyarakat-petani-dan masyarakat-nelayan-di-kabupaten-brebes/, diakses hari Minggu tanggal 7 Oktober 2021

Sanapiah Faisal, Sosiologi Pendidikan, Surabaya: Usana Offset Printing. 